\title{
Philippines brain drain: Fact or fiction?
}

$\mathrm{E}$ very Filipino medical professional knows the statistic. In recent years, this Southeast Asian nation has ranked number one for exporting nurses and number two for sending doctors overseas, according to the University of the Philippines in Manila.

Between 2004 and 2010, nearly 72000 Filipino nurses were newly employed or rehired abroad, according to data from the Philippine Overseas Employment Administration. The latest specific numbers date back to 2008, when then-health secretary Francisco Duque estimated that $85 \%$ of Filipino nurses were working in Western countries, while $70 \%$ of Filipinos were dying without medical attention - a death rate not seen since the 1970s.

But Kenneth Ronquillo, director of the Health Human Resource Development Bureau of the Department of Health, says the much-reported brain drain is, in fact, a myth.

"In terms of absolute doctors and nurses, the Philippines has always had an ample supply," he says.

And in the wake of the 2008 global financial crisis, the Philippines may actually be facing the opposite problem - a surplus - as a result of the fall in overseas demand. In mid-2011, the Philippine Nurses Association warned that 287000 nurses in this country of 90 million people were either unemployed or lacking sufficient hours.

The other key concern has been that, too often, the best-qualified and best-trained doctors and nurses are the ones who leave. Though overseas demand has, conversely, raised domestic standards, says Ronquillo.

"The international community preference for our experienced nurses has led to higher expenditures for training and development of fresh, local graduates," he says, adding that Western countries typically require two to three years prior experience.

The real problem in the Philippines, says Ronquillo, is that money is not

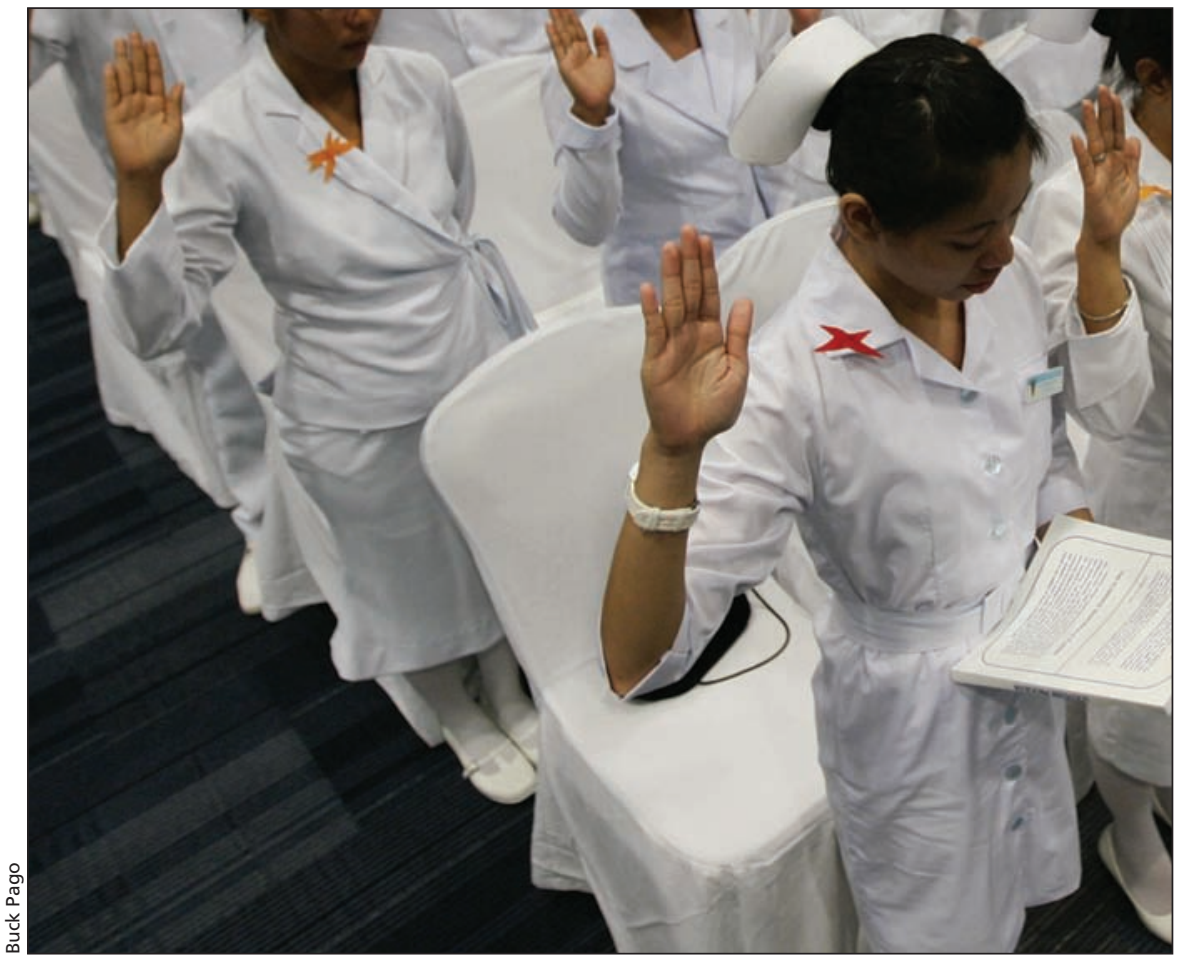

The brain drain is a myth in the Philippines, but shortages of health professionals abound in rural areas.

being spent to make sure that medical human resources are spread equitably across this archipelago nation; remote areas are not only lacking doctors and nurses, but also hospitals and clinics.

Although a drive to employ more state health workers prompted a $30 \%$ increase in the number of doctors hired and a $21.5 \%$ rise in nurses in 2012, according to the Department of Health, numbers are still inadequate nationwide.

Dr. Carmella Cunanan, a rural health physician outside of Davao, the country's third-largest city, says there should be nine state doctors working alongside her in Talomo District, home to 200000 people. Instead, she works alone. Similarly, there should be 20 nurses in the area - one per 10000 people - but there are only 6 , and there should be 40 midwives instead of just 5 .

"There are no permanent positions created," says Cunanan.

It's a problem also noted by Ronquillo, who, even as the head of the
Philippines Department of Health personnel department, still says he has little say over how many positions are created.

Starting in the early 1990 s, the Philippines began to devolve a number of government functions - including health care - to local authorities. Critics of the system say this has seen national health care policy succumb to the whims of local politicians.

"It's our mayor who appoints permanent doctors and nurses, and we just recommend," says Cunanan.

Dr. Josephine Villafuerte, the Davao City health officer, says that the expanding private sector and overseas demand for Filipino health workers has not helped by offering better salaries, which in turn has driven higher wages in the state sector. "Lately, though, the [health] budget in Davao has stayed the same," she adds.

In Davao, nurses are paid more than 30000 pesos $(\$ 750)$ per month, she says, about five times less than a 
nurse in Canada but more than double the average income in the Philippines. Villafuerte says this is perhaps how brain drain has contributed to the real problem.

In 2011, the World Health Organization ranked the Philippines 170th in the world on health spending, as just 3.6\% of its gross domestic product was spent on health services.

An hour and a half by bus north of Davao City in the small town of Marilog, the lack of spending is all too apparent. In 2002, a congressman built a brand new hospital with his congressional funds, but 11 years later it is still not connected to the municipal electricity and water supplies. There is a generator, but it is no longer used, says a receptionist — the diesel is too expensive.

With no power or water, this health facility has slowly fallen into disrepair. The operating theater is padlocked and in one empty ward, gynecology examination tables have still not been unpacked from their boxes.

The only doctor here tends to 60000 people scattered over hills and valleys across 11 other districts, meaning consultations are only available at Marilog hospital on Mondays. The rest of the week the doors remain closed.

Dulcisimo Emberador, a 77-year-old retiree, lives about 100 meters from the hospital gates. But when he came down with a fever last month — on a Tuesday - he says he had to travel to the town of Calinan to see a doctor. "It's 35 kilometres away," he said. — Steve Finch, Davao, the Philippines

CMAJ 2013. DOI:10.1503/cmaj.109-4459 